\title{
Effects of copper in sediments on benthic macroinvertebrate communities in tropical reservoirs
}

\author{
Beghelli, FGS ${ }^{1}$, Pompêo, MLM², Rosa, $\mathrm{AH}^{1}$ and Moschini-Carlos, $\mathrm{V}^{1}$ \\ ${ }^{1}$ Universidade Estadual Paulista "Júlio de Mesquita Filho" - UNESP, Sorocaba, SP, Brazil. \\ ${ }^{2}$ Universidade de São Paulo - USP, São Paulo, SP, Brazil. \\ * Corresponding author: fred_sb@hotmail.com
}

Received: 10/11/2014

Accepted: 25/08/2015

\begin{abstract}
Effects of copper in sediments on benthic macroinvertebrate communities in tropical reservoirs

Copper $(\mathrm{Cu})$ is an essential trace element but can be toxic to biota when present above a certain threshold concentration. There are many anthropogenic sources of copper, which can accumulate in sediments. Benthic macroinvertebrates (BMI) are organisms that inhabit the sediments, so they can be good indicators of sediment toxicity. The objective of this work was to test BMI community responses to a range of $\mathrm{Cu}$ concentrations in sediments. For this purpose, we used mouthpart alterations and bioaccumulation as endpoints. Sediment samples were collected, and in situ analyses of water variables were conducted at nine sampling points distributed along three interconnected reservoirs of the Cantareira System in Sao Paulo State, Brazil. Copper concentrations were determined in the sediments, chironomid larvae and oligochaetes. The results indicated that contamination of the sediments collected from the Paiva Castro reservoir was sufficient to cause $\mathrm{Cu}$ bioaccumulation in larval Chironomidae. No bioaccumulation was observed in oligochaetes or in any of the organisms from control locations. A linear model, rather than the logistic model generally considered in dose-response assays, best fitted the observed mouthpart alterations and $\mathrm{Cu}$ concentrations. Extrapolation of the model indicated that a $\mathrm{Cu}$ concentration of $58.60 \mathrm{mg} / \mathrm{Kg}$, instead of the proposed PEL value of $108 \mathrm{mg} / \mathrm{Kg}$, would be sufficient to cause observable alterations in $50 \%$ of the Chironomidae larvae. Moreover, our results showed that $\mathrm{Cu}$ levels higher than $13 \mathrm{mg} / \mathrm{Kg}$ can cause adverse effects in BMI communities and that the levels found in the Paiva Castro reservoir (15.19-41.18 mg/Kg) were sufficient for bioaccumulation in chironomids.
\end{abstract}

Key words: Ecotoxicology, macroinvertebrate community, Chironomidae, tropical reservoirs.

\section{RESUMO}

\section{Efeitos do cobre ( $\mathrm{Cu}$ ) sobre a comunidade de macroinvertebrados em sedimentos de reservatórios tropicais}

$\mathrm{O} \mathrm{Cu}$ é um elemento traço essencial que pode tornar-se tóxico para a biota quanto ocorre em concentrações acima de determinados valores. Há diferentes fontes antrópicas deste metal que acaba por se acumular nos sedimentos. Os macroinvertebrados bentônicos (BMI) são organismos que vivem nos sedimentos e são considerados bons bioindicadores. Para tanto, alterações em peças bucais, consideradas neste estudo como qualquer alteração observável, e bioacumulação, foram as respostas biológicas analisadas. Amostras da água e dos sedimentos foram coletadas em nove pontos amostrais distribuídos ao longo de três reservatórios do Sistema Cantareira, São Paulo, SP, Brasil. As concentrações de Cu nos sedimentos, larvas de Chironomidae e Oligochaeta foram determinadas. Os resultados indicam que os sedimentos do reservatório Paiva Castro estão contaminados por $\mathrm{Cu}$ em concentrações suficientes para provocar bioacumulação em larvas de Chironomidae. Não foi observada bioacumulação em Oligochaeta ou nas amostras controle. Foi obtido um modelo linear ao invés do modelo logístico, geralmente utilizado em ensaios de dose-resposta, relacionando as alterações em peças bucais com as concentrações de Cu nos sedimentos. A extrapolação do modelo indica que concentrações da ordem de $58.60 \mathrm{mg} / \mathrm{Kg}$, valor bem inferior ao proposto para PEL de $108 \mathrm{mg} / \mathrm{Kg}$, já seriam suficientes para provocar efeitos observáveis em $50 \%$ das larvas. Ademais, nossos resultados demonstram que níveis de Cu acima de $13 \mathrm{mg} / \mathrm{Kg}$ podem ocasionar efeitos adversos sobre a comunidade BMI e que, além disso, as concentrações registradas no Paiva Castro (15.19-41.18 mg/Kg) já são suficientes para resultar em bioacumulação em quironomídeos.

Palavras chave: Ecotoxicologia, macroinvertebrados, Chironomidae, Cobre, reservatórios tropicais. 


\section{INTRODUCTION}

Copper is an essential trace element for living organisms but can be toxic at high concentrations. Common causes of $\mathrm{Cu}$ contamination of water bodies include discharges of industrial effluents (Yi et al., 2011), mining activities (Varol \& Şen, 2012), metal processing (Yi et al., 2011), and its presence in compounds used as pesticides in agriculture (El Azzi et al., 2013) or algaecides applied directly into the water (Fontana et al., 2014).

Sediments gradually accumulate metals and other pollutants (Bing et al., 2013), which can then be released into the water column when environmental conditions change (Akcil et al., 2014). Furthermore, even if it is not released into the water, copper can have impacts on the organisms living in contact with the sediments, affecting the distribution and composition of their communities. Bioaccumulation can occur in benthic macroinvertebrates (BMI) or at higher trophic levels due to transfer through the food chain (Walls et al., 2013).

BMI live in direct association with the sediments and are mainly sessile or have low mobility. They can survive in a wide variety of habitats and have high species diversity. These characteristics enable them to serve as good bioindicators (Mandaville, 2002; Blijswijk et al., 2004). Moreover, because BMI communities are mainly composed of detritivores, they are directly exposed to metals that are present together with particulate organic matter (Hogsden \& Harding, 2012).

In metal-polluted environments BMI show responses at different levels of organization (com-
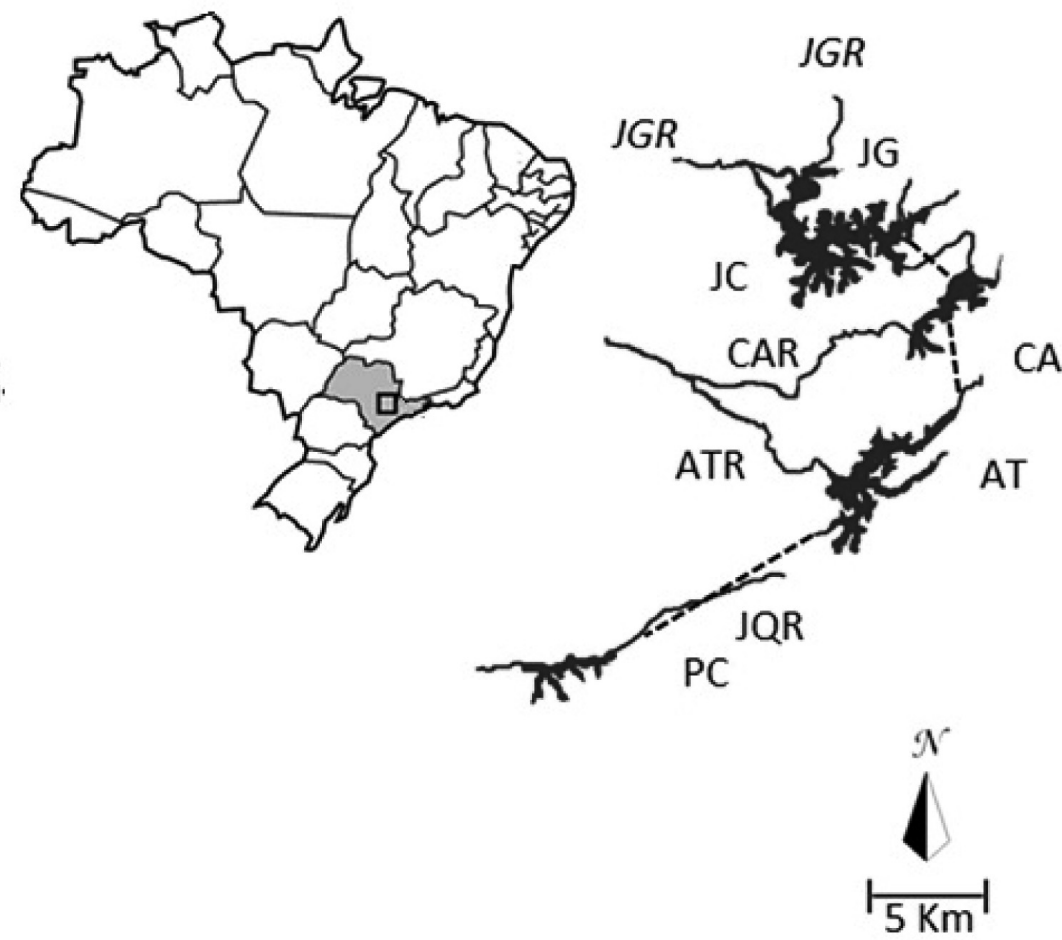

Figure 1. (Right) Approximate location of the Cantareira System in São Paulo State, Brazil. (Left) The Cantareira System and its main tributaries and reservoirs as follows: the Jaguari (JGR), Cachoeira (CAR), Atibaia (ATR), and Juqueri rivers (JQR), and the Jaguari (JG), Jacareí (JC), Cachoeira (CA), Atibaia (AT, not included in the present study), and Paiva Castro reservoirs (PC). The connecting tunnels between the reservoirs are represented by dashed lines. The connecting tunnels between the reservoirs are represented by dashed lines. A direita: localização aproximada do Sistema Cantareira no estado de São Paulo, Brasil. A esquerda: $O$ Sistema Cantareira com seus principais afluentes e reservatórios: rio Jaguari (JGR), rio Cachoeira (CAR), rio Atibaia (ATR), rio Juqueri (JQR); reservatório Jaguari $(J G)$, reservatório Jacareí (JC), reservatório Cachoeira $(C A)$, reservatório Atibaia (AT, não contemplado neste estudo) e reservatório Paiva Castro $(P C)$. Os túneis que conectam os reservatórios estão representados pela linha tracejada. 
munity, population, or individuals), and a relationship exists between deformities in chironomid larvae and environmental pollution due to metals and pesticides. In broad terms, three types of studies have been conducted as follows: (1) environmental characterization and the association of deformities with areas subject to greater pollution by several metals (Ryu et al., 2011), (2) laboratory simulations in which only one species is tested (Di Veroli et al., 2012) and (3) pollution assumed because of the presence of deformities (Odume et al., 2012).

Our hypothesis was that the sediment levels of $\mathrm{Cu}$ in the Paiva Castro reservoir are sufficient to cause bioaccumulation and morphological changes in benthic macroinvertebrates and that these responses can be used to assess $\mathrm{Cu}$ contamination. Thus, we investigated the response of $\mathrm{BMI}$ to $\mathrm{Cu}$ present in the sediments at a range of concentrations in some of the most important reservoirs used for public water supply in Brazil to contribute to the determination of safe levels of $\mathrm{Cu}$ in the sediments of tropical environments.

\section{MATERIALS AND METHODS}

\section{Study area}

The Cantareira System is a series of interconnected rivers and reservoirs designed to provide water to the Metropolitan Region of São Paulo. It supplies water to $58 \%$ of the region's 17.2 million people. The system diverts water from five main rivers, the Jaguari, Jacareí, Atibaia, Cachoeira, and Juqueri (Paiva Castro), which passes through tunnels and channels that link reservoirs with the same names (Fig. 1; Whately \& Diniz, 2009).

The Cantareira System is located in an urbanized region that was originally a tropical rainforest biome. According to the Instituto Socioambiental (ISA), in 2003, 69.4\% of the area was used for anthropic purposes, and only $21 \%$ remained covered with Atlantic rainforest. There is a high level of anthropic use (79.4\%) in the Cachoeira basin, but the urbanized area is small $(0.8 \%)$. In contrast, the Juqueri basin has a greater area covered with natural vegetation $(37 \%)$, with lower anthropic usage (52.2\%); $9.3 \%$ of the area is used for urban settlement (Whately \& Cunha, 2007).

$\mathrm{Cu}$ has accumulated in the sediments of the Paiva Castro reservoir (Cardoso-Silva, 2013). Pompêo (2012) reported that copper sulfate was added to the Atibaia outflow just before the junction with the Juqueri River to reduce the proliferation of algae caused by eutrophication.

In previous research (Beghelli et al. 2014), the concentrations of $\mathrm{Al}, \mathrm{As}, \mathrm{Cd}, \mathrm{Cr}, \mathrm{Cu}, \mathrm{Fe}$, $\mathrm{Ni}, \mathrm{Pb}$ and $\mathrm{Zn}$ were analysed in samples obtained from the same sampling points used in this study. Probable contamination of the sediments of the Cantareira System by $\mathrm{Cd}, \mathrm{Cr}$ and $\mathrm{Cu}$ was indicated. Cadmium and copper concentrations were higher in the Paiva Castro reservoir, and chromium, in the Jaguari-Jacareí and Cachoeira.

\section{Sampling design}

Nine sampling locations were chosen along three reservoirs as follows: the Jaguari-Jacareí (JGJC), which operates as a unity; Cachoeira (CA); and Paiva Castro (PC), during July and August 2013 (supplementary material). To obtain samples rich in macroinvertebrates, littoral sampling sites were used with depths of approximately $3 \mathrm{~m}(3.23 \pm 0.5)$. For bioaccumulation analysis, CA3 was used as a control.

\section{Water and sediments}

At every sampling point, in situ measurements of $\mathrm{pH}$, electrical conductivity, dissolved oxygen, and temperature were made using a Horiba U50 multiprobe, and transparency was measured with a Secchi disk. The measurements were made close to the reservoir beds.

Sediment samples were collected using an Ekman dredge $\left(208 \mathrm{~cm}^{2}\right)$. In the laboratory, a portion of each sample was separated for grain size and organic matter determinations, with a separate portion being used for metal analysis. For organic matter and grain-size analysis, the material was previously dried at $100{ }^{\circ} \mathrm{C}$ for $2 \mathrm{~h}$, sieved $(0.2 \mathrm{~mm})$, and weighed with an analytical balance (Shimadzu AUX 220) to a precision of $1 \mathrm{mg}$. The proportion of organic matter was determined 
as described by Wetzel \& Likens (2000), and the relative amounts of fine $(<0.212 \mathrm{~mm})$ and coarse inorganic and organic matter were calculated.

The total $\mathrm{Cu}$ and $\mathrm{Al}$ concentrations in the sediments were determined (in triplicate) by ICPOES (Agilent Technologies 700 Series) according to Method 3050B (USEPA, 1996). A digitally controlled heater plate (Quimis, Q313M) was used to improve sample digestion, and a multi-element $100 \mathrm{mg} / \mathrm{L}$ standard solution (SpecSol G16V) was employed to prepare fortified solutions for calibration and method validation. The values obtained for $\mathrm{Cu}$ concentrations in the sediments were normalized by calculating the enrichment factor (Sutherland, 2000). Because the data were obtained from littoral samples for which no reference values are available for the study area, the reference value for aluminum was considered to be the mean for all sampling points, excluding the outliers. For $\mathrm{Cu}$, the reference value used was that calculated by Cardoso-Silva (2013) for the Paiva Castro reservoir.

\section{Benthic macroinvertebrates}

The BMI were collected using three dredgings per sampling point. Density, richness - as the number of species - and the Shannon index were calculated. The proportions of mouthpart alterations (ALT) were calculated considering the entire family Chironomidae. The term "alterations" was adopted instead of "deformities" because the analysis considered any observable mouthpart alterations. The following criteria were used to identify an alteration: symmetry, comparisons of the right and left sides relative to the longitudinal axis (Sanseverino \& Nessimian, 2009), comparisons with the same taxon at the same sampling point, and comparisons with information available in the literature (Bird, 1994; Epler, 2001; Trivinho-Strixino, 2011; Odume et al., 2012). Each specimen was analysed three times, ensuring that the analyst had no prior knowledge of the location from which it was obtained (to avoid any subjective bias). Doubtful situations were not considered.

The samples used to determine $\mathrm{Cu}$ in the organisms were from locations CA3 - which was considered to be the control- and PC. The Cachoeira reservoir was considered a control because it presented better values for water quality (Whately \& Cunha, 2007) and is located upstream from the applications of copper sulfate (Pompêo, 2012). The Jaguari-Jacareí reservoir was not considered to be a control because it is under greater anthropic pressure, given its trophic state, coliform concentrations and land uses (Whately \& Cunha, 2007).

Digestion was performed according to the method proposed by Soares (2012) using $\mathrm{HNO}_{3}$ and $\mathrm{H}_{2} \mathrm{O}_{2}$, which was modified to reduce the error of the balance by weighing more than one specimen (up to five specimens or $5 \mathrm{mg}$ humid weight per sampling point/taxon). The results were calculated in terms of dry weight. The certified reference material (CRM) used for quality control was fish muscle (ERM BB422). The numbers of tubes -containing up to five specimens or $5 \mathrm{mg}$ - analysed per sampling point were 2 chironomids and 3 oligochaetes from $\mathrm{PC} 1$, 3 chironomids and 2 oligochaetes from PC2, 3 chironomids from PC3, and 2 chironomids from CA3.

Fortified solutions were prepared by the addition of a standard solution (SpecSol AAS, $100 \mathrm{mg} / \mathrm{L}$ ), and each sample was analysed in triplicate using graphite furnace atomic absorption spectrometry (GFAAS - Varian, AA240Z). The GFAAS operating conditions were as follows: a wavelength of $327.4 \mathrm{~nm}$, drying at $85-120^{\circ} \mathrm{C}$, pyrolysis at $1200{ }^{\circ} \mathrm{C}$, atomization at $2500^{\circ} \mathrm{C}$, and clean-out at $25500^{\circ} \mathrm{C}$. The modifier used was $100 \mathrm{mg} / \mathrm{L} \mathrm{Pd}$ in $5 \%(\mathrm{v} / \mathrm{v}) \mathrm{HNO}_{3}(5 \mu \mathrm{L}$ co-injection). The analytical curve was constructed using $\mathrm{Cu}$ concentrations of 300,210 , 150,90 , and $30 \mu \mathrm{g} / \mathrm{L}$. Bioaccumulation indices (BAI) were calculated by dividing the difference between the $\mathrm{Cu}$ concentrations in the sediments and the organisms by the $\mathrm{Cu}$ concentration in the sediments. Positive values reflected bioaccumulation, and negative values indicated its absence.

\section{Analytical validation}

The limits of quantification (LQ) were calculated by dividing 10 times the standard deviation of 10 
Table 1. Bottom water variables: $\mathrm{pH}$, temperature $\left(\mathrm{T},{ }^{\circ} \mathrm{C}\right)$, dissolved oxygen $(\mathrm{DO}, \mathrm{mg} / \mathrm{L})$, transparency as Secchi disk visibility depth (Trans, $\mathrm{m})$ and electric conductivity $(\mathrm{EC}, \mu \mathrm{S} / \mathrm{cm})$. Variáveis da água do fundo: $\mathrm{pH}$, temperature $\left(\mathrm{T}\right.$, $\left.{ }^{\circ} \mathrm{C}\right)$, oxigênio dissolvido $(D O, m g / L)$, transparência por leitura do disco de Secchi (Trans, $m)$ e condutividade elétrica $(E C, \mu S / \mathrm{cm})$.

\begin{tabular}{cccccc}
\hline & $\mathrm{pH}$ & $\mathrm{T}$ & $\mathrm{DO}$ & Trans & EC \\
\hline $\mathrm{JC} 1$ & 7.30 & 18.00 & 8.13 & 2.0 & 49 \\
$\mathrm{JC} 2$ & 6.97 & 18.84 & 8.13 & 1.5 & 34 \\
$\mathrm{JG} 1$ & 7.66 & 18.60 & 9.74 & 2.0 & 37 \\
$\mathrm{CA} 1$ & 7.34 & 18.00 & 11.22 & 2.8 & 31 \\
$\mathrm{CA} 2$ & 6.83 & 18.53 & 11.59 & 2.0 & 33 \\
$\mathrm{CA3}$ & 7.05 & 17.45 & 8.90 & 3.0 & 33 \\
PC1 & 6.40 & 17.64 & 8.12 & 1.2 & 33 \\
PC2 & 6.21 & 17.03 & 7.59 & 1.2 & 35 \\
PC3 & 6.20 & 17.82 & 7.45 & 2.7 & 34 \\
\hline
\end{tabular}

blank readings by the slopes of the calibration curves. Fortified solutions $\left(2 \% \mathrm{HNO}_{3}+\right.$ a metal standard solution) were prepared as controls for the sediment samples (see Table 1, EC). For the BMI analyses, we used fortified solutions and certified reference materials to calculate the analytical recovery (AR) and standard error (SE) according to equations (1) and (2):

$$
\begin{aligned}
& A R=\left(\frac{C}{R C}\right) \times 100 \\
& S E=\left(\frac{(C-R C)}{R C}\right) \times 100
\end{aligned}
$$

where $C$ and $R C$ are the measured and expected values, respectively.

\section{Statistical analyses}

Statistical analyses were performed using R software (R Core Team, 2013). The sediment variables were normalized using $\mathrm{z}$-scores, and their relationships with the $\mathrm{Cu}$ concentrations were calculated using the Spearman correlation test. Analysis of variance (ANOVA) was performed using blocks (where a block corresponded to a taxon) to test the effect of the enrichment factor on BAI, and simple ANOVA was used to test the effects of metal concentrations or enrichment factors on ALT.

Different regression models were tested to model the relationships between ALT and $\mathrm{Cu}$ levels, as well as the relationships between ALT and enrichment factors. A 95\% confidence interval was calculated for the model with 1000 simulations (Logan, 2010).

Table 2. Sediment variables. Fine and coarse organic matter percentages (FOM and COM), fine and coarse inorganic matter percentages (FS and CS), total copper concentrations $(\mathrm{mg} / \mathrm{Kg})$, total aluminum concentrations $(\mathrm{g} / \mathrm{Kg})$, and copper enrichment factors $\left(\mathrm{Cu}_{\text {norm }}\right)$ adapted from Sutherland (2000). Valores registrados para as variáveis referentes aos sedimentos. Porcentagens de matéria orgânica fina e grosseira (FOM e COM); porcentagens de sedimento inorgânico fino e grosseiro (FS e CS); concentrações de cobre

\begin{tabular}{|c|c|c|c|c|c|c|c|}
\hline & FOM & $\mathrm{COM}$ & FS & CS & $\mathrm{Cu}$ & $\mathrm{Al}$ & $\mathrm{Cu}_{\text {norm }}$ \\
\hline $\mathrm{JC} 1$ & 14.29 & 0.00 & 64.93 & 20.77 & 16.54 & 75.12 & 0.42 \\
\hline $\mathrm{JC} 2$ & 4.96 & 0.00 & 33.15 & 61.89 & 12.05 & 53.14 & 0.43 \\
\hline JG3 & 9.38 & 0.00 & 27.85 & 62.76 & 11.21 & 61.72 & 0.34 \\
\hline CA1 & 14.92 & 1.66 & 76.41 & 7.02 & 25.03 & 70.48 & 0.67 \\
\hline $\mathrm{CA} 2$ & 5.41 & 0.00 & 31.56 & 63.02 & 10.21 & 30.55 & 0.63 \\
\hline $\mathrm{CA} 3$ & 3.84 & 1.63 & 74.86 & 19.68 & 12.51 & 27.16 & 0.87 \\
\hline $\mathrm{PC} 1$ & 2.62 & 10.23 & 88.86 & 0.00 & 20.98 & 18.31 & 2.17 \\
\hline PC2 & 6.60 & 9.44 & 85.65 & 0.00 & 41.18 & 58.46 & 1.34 \\
\hline PC3 & 3.78 & 4.69 & 73.13 & 18.40 & 15.19 & 14.87 & 1.94 \\
\hline
\end{tabular}
total $(\mathrm{mg} / \mathrm{Kg})$; concentrações de alumínio total $(\mathrm{g} / \mathrm{Kg})$ e fator de enriquecimento para cobre $\left(\mathrm{C} \mathrm{u}_{\text {norm }}\right)$ adaptado de Sutherland $(2000)$. 


\section{RESULTS}

\section{Water and sediments}

In the reservoirs, conductivity varied from 32.33 to $40.00 \mu \mathrm{S} / \mathrm{cm} ; \mathrm{pH}$, from 6.27 to 7.31 ; temperature, from 17.50 to $18.48{ }^{\circ} \mathrm{C}$; dissolved oxygen, from 7.72 to $10.57 \mathrm{mg} / \mathrm{L}$; and transparency, from 1.83 to $2.58 \mathrm{~m}$ (Table 1$)$. The values obtained to characterize the sediments are given in Table 2 . Spearman correlations showed positive relationships for $\mathrm{Cu}$ with coarse organic (COM) and fine inorganic matter $(\mathrm{FS})\left(r_{S}>0.80\right)$. A weaker relationship was obtained between $\mathrm{Cu}$ and the conservative element $\mathrm{Al}\left(r_{S}=0.62\right)$.

\section{Benthic macroinvertebrate community}

Higher densities were recorded in the Paiva Castro reservoir, and lower values, in Cachoeira.

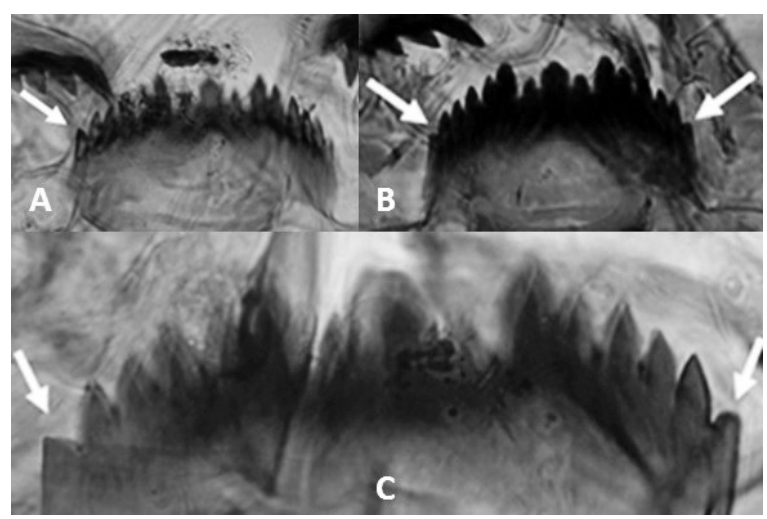

Figure 2. Three menta of Chironomus sp., showing last lateral teeth. (A) Normal condition; (B) and (C) reduction of the last lateral tooth. Três mentos de Chironomus sp. mostrando o último dente lateral. (A) Condição normal; (B) e (C) redução do último dente lateral.
Densities varied from 16 (CA2) to $1234 \mathrm{ind} / \mathrm{m}^{2}$ (PC1). Chironomidae predominated in most sampling points, except in $\mathrm{JC} 1$, where Oligochaeta was the major taxonomic group. Sampling stations JC2, CA1 and CA2 had no record of Oligochaeta.

The number of taxa varied from 1 to 15 , and the Shannon index from 0.00 to 2.30 . Higher richness and diversity indices were recorded in the Paiva Castro reservoir at PC2 and PC3; lower values were recorded in Cachoeira -CA1 and $\mathrm{CA} 2-$ and the Jacareí sampling station JC2 (Table 3). No effects were observed for $\mathrm{Cu}$ concentrations on richness, density or diversity $(p>0.05)$.

\section{Mouthpart alterations (ALT)}

No relationship was found between ALT and any other metal $(p>0.05)$, with the exception of copper. Total $\mathrm{Cu}$ concentrations were related to ALT $(p=0.002)$ but not to the enrichment factor $(p=0.37)$. Mouthpart alterations were mainly seen in Chironomus spp. ( $\mathrm{PC} 1=8$, PC3 = 2), Polypedilum spp. (PC2 = 12), Tanytarsus $\quad$ spp. $\quad(\mathrm{JC} 2=5, \quad \mathrm{JG} 1=1, \quad \mathrm{CA} 3=1$, $\mathrm{PC} 2=3, \quad \mathrm{PC} 3=1)$, and tanypodine larvae $(\mathrm{JC} 1=1, \quad \mathrm{CA} 1=1, \quad \mathrm{CA} 3=1, \quad \mathrm{PC} 2=1 \quad$ and PC3 = 2) (Figs. 2-6). The most common alteration was the reduction of one or more teeth in the mentum. The most evident alterations were observed in the Tanypodinae, which have predatory or omnivorous behaviours (Fig.4). ALT varied from 0.06 to 0.37 according to the sampling point (Fig. 7). Fewer than three organisms were sampled for CA1 and CA2, so those values were not considered. The relationship between ALT and $\mathrm{Cu}$

Table 3. Oligochaeta, Chironomidae and total density values (ind $/ \mathrm{m}^{2}$ ); richness (number of species or genera) and diversity (Shannon index). Densidades de Oligochaeta, Chironomidae e totais (ind $/ \mathrm{m}^{2}$ ); riqueza como número de espécies ou gêneros e diversidade de Shannon.

\begin{tabular}{cccccccccc}
\hline & JG1 & JC2 & JC3 & CA1 & CA2 & CA3 & PC1 & PC2 & PC3 \\
\hline Oligochaeta & 545 & 0 & 96 & 0 & 0 & 16 & 433 & 32 \\
Chironomidae & 128 & 689 & 609 & 48 & 16 & 208 & 801 & 657 \\
Density & 673 & 689 & 705 & 48 & 16 & 224 & 1234 & 689 & 481 \\
Richness & 10.00 & 5.00 & 9.00 & 3.00 & 1.00 & 7.00 & 15.00 & 11.00 & 14.00 \\
Diversity & 1.43 & 0.93 & 1.39 & 1.10 & 0.00 & 1.73 & 1.81 & 2.06 & 2.30 \\
\hline
\end{tabular}




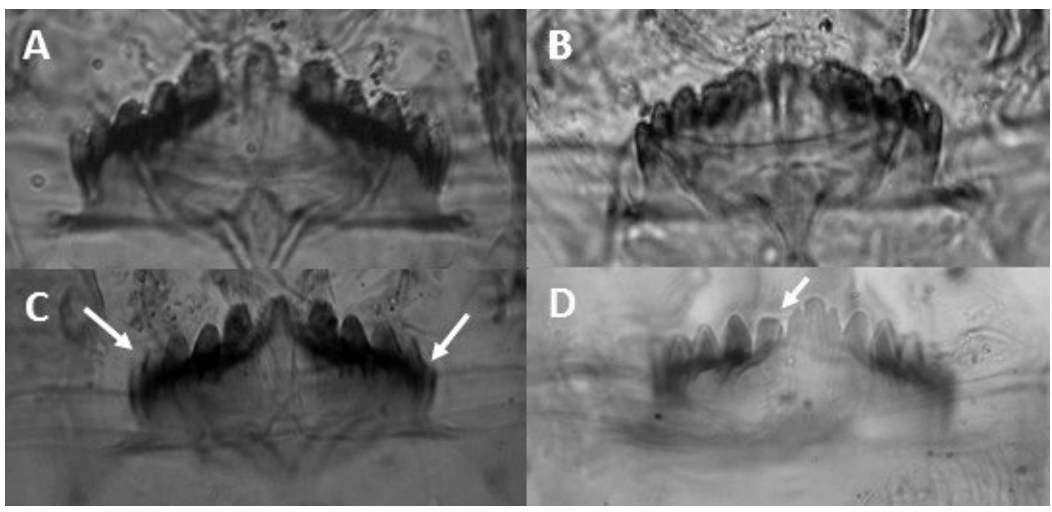

Figure 3. Mentum of Tanytarsus sp. larvae. (A) Normal mentum; (B) mentum with many reduced teeth; (C) mentum with two reduced teeth (left $4^{\text {th }}$ and right $5^{\text {th }}$ lateral); (D) reduced left $1^{\text {st }}$ lateral tooth. Mentos de larva de Tanytarsus sp. (A) Mento normal; (B) mento com diversos dentes reduzidos; $(C)$ mento com dois dentes reduzidos ( $4^{\circ}$ esquerdo e $5^{\circ}$ direito laterais); (D) redução do $1^{\circ}$ dente lateral do lado esquerdo.

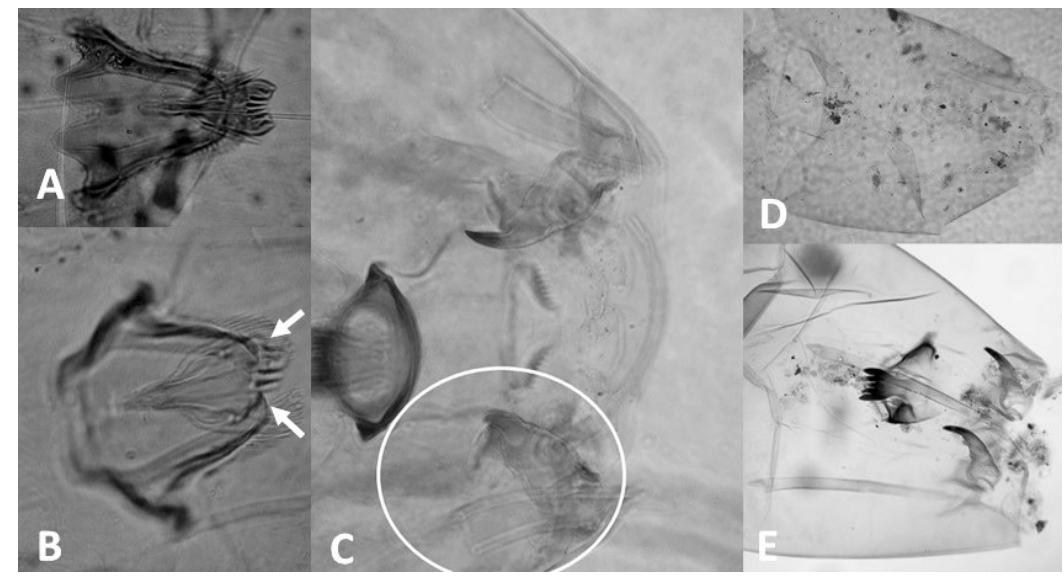

Figure 4. (A) and (B): Tanypodine larvae. Ligula from Coelotanypus sp. without alterations (A) and abnormal with absence of three teeth (B). (C), (D), and (E): Djalmabatista sp. larvae. Deformed mandible (C); apparent absence of mouthparts (D); normal condition (E). (A) e (B): larvas de Tanypodinae. Lígula de Coelotanypus sp: Sem alterações $(A)$ e anormal com ausência de três dentes $(B)$. $(C),(D)$ e (E): larvas de Djalmabatista sp. Mandíbula deformada (C), aparente ausência de peças bucais $(D)$ e condição normal $(E)$.

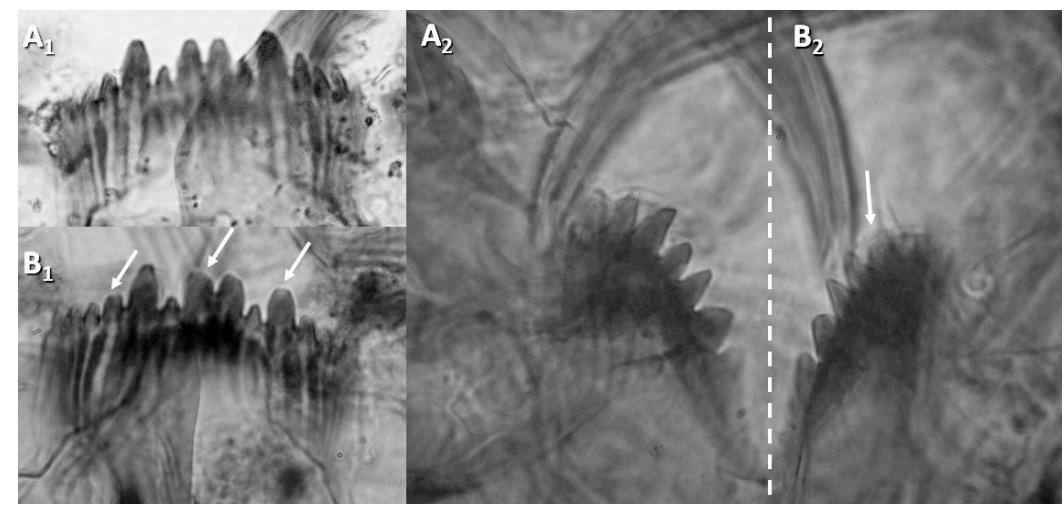

Figure 5. Mentum of Polypedillum sp. larvae. $\left(\mathrm{A}_{1}\right)$ Normal condition and $\left(\mathrm{B}_{1}\right)$ multiple tooth reductions. A Fissimentum sp. separated mentum showing normal condition in $\left(\mathrm{A}_{2}\right)$ and a reduction in the $5^{\text {th }}$ lateral tooth. Mentos de larvas de Polypedillum sp. (A) Condição normal e (B) apresentando redução de múltiplos dentes. Um mento de Fissimentum sp está dividido mostrando a condição normal em $\left(A_{2}\right)$ e a redução do $5^{\circ}$ dente lateral em $\left(B_{2}\right)$. 


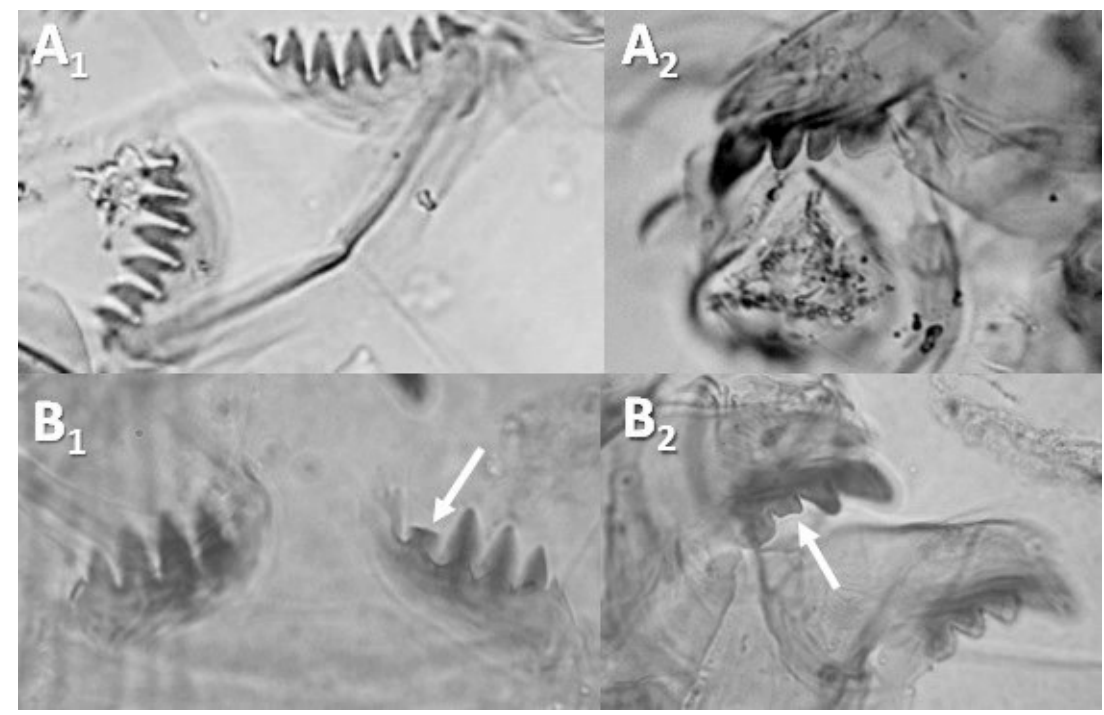

Figure 6. Alterations observed in mouthparts other than the mentum. $\left(\mathrm{A}_{1}\right)$ a dorsomental plate of a Djalmabatista sp. larva in normal condition and $\left(\mathrm{B}_{1}\right)$ with the reduction of one tooth. $\left(\mathrm{A}_{2}\right)$ Tanytarsus sp. mandible in normal condition and $\left(\mathrm{B}_{2}\right)$ with the reduction of one tooth. Alterações observadas outras peças bucais além do mento. $\left(A_{1}\right)$ mostra uma placa dorsomental de uma larva de Djalmabatista sp na sua condição normal e $\left(B_{1}\right)$ com a redução de um dente. Em $\left(A_{2}\right)$ é observada uma mandíbula de Tanytarsus sp na condição normal e em $\left(B_{2}\right)$ nota-se a redução de um dente.

sediment concentrations could be explained by a linear model $\left(R^{2}=0.86\right.$; Fig. 8, Eq. 3).

$$
\mathrm{ALT}=0.0077 \times\left[\mathrm{Cu}_{\mathrm{sed}}\right]+0.0488
$$

\section{Bioaccumulation}

The bioaccumulation indices (BAI) showed positive values for the Chironomidae but not for the Oligochaeta. No bioaccumulation was observed at $\mathrm{CA} 3$. Elsewhere, $\mathrm{Cu}$ concentrations in the chironomids were between 30 and $110 \%$ higher than in the sediments (Fig. 8). The ANOVA results indicated an effect of the normalized $\mathrm{Cu}$ concentrations in the sediments on the concentrations in the organisms $(p=0.025)$ and that the response differed between the oligochaetes and chironomids $(p=0.039)$.

The limits of quantification for the $\mathrm{Cu}$ and $\mathrm{Al}$ analysed in the sediments were 0.090 and 0.030 $\mathrm{mg} / \mathrm{Kg}$. The analytical recovery varied between 99.75 and $115.15 \%$ for the GFAAS analyses. For the ICP analyses, it varied between 84.00 to $96.30 \%$. Additional details are given in the supplementary material.

\section{DISCUSSION}

None of the water variables considered here apparently acted as a limiting factor or stressor. From a general perspective, the Cachoeira reservoir showed some conditions usually associated with a lower trophic state, such as a higher dissolved oxygen concentration and transparency, as well as lower conductivity. In the sediments, higher proportions of organic matter were found for the Jaguari-Jacareí and Paiva Castro reservoirs, with the latter exhibiting higher levels of coarse organic matter and fine inorganic sediment. These differences could explain the differential availability of $\mathrm{Cu}$ in the environment because the metal forms complexes with organic matter and is adsorbed by fine particles (Shafie et al., 2013), as was observed here.

At the Paiva Castro reservoir, the $\mathrm{Cu}$ concentration in the sediments at PC2 was significantly higher than the value of $24 \mathrm{mg} / \mathrm{Kg}$ found previously (Cardoso-Silva, 2013). The enrichment factors values for PC1 and PC3 (see Table 2) were above those expected for natural conditions without anthropic Al inputs, according to the limits proposed by Sutherland (2000), which estab- 
A

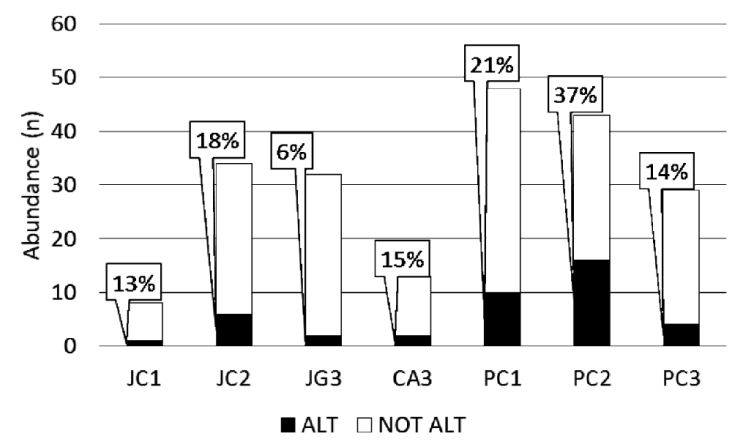

B

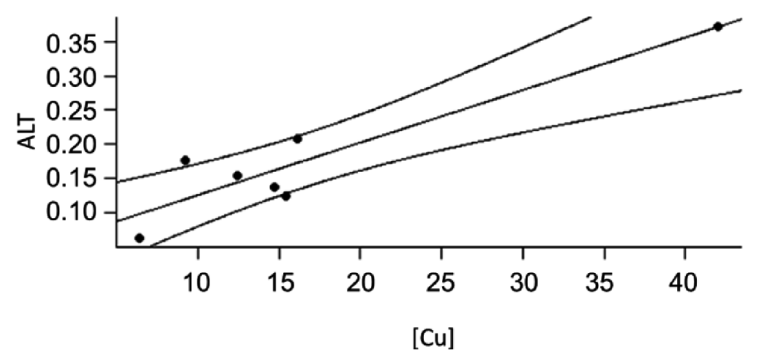

Figure 7. (A) Percentages of chironomid larvae with or without mouthpart alterations according to sampling station. The balloons show the relative proportions of larvae with alterations. (B) Linear relationship (95\% confidence interval) between the total copper in sediments $\left[\mathrm{Cu}_{\text {sed }}\right](\mathrm{mg} / \mathrm{Kg})$ and the proportions of mouthpart alterations in chironomid larvae (ALT) obtained with data for 207 chironomid larvae from six sampling points at three reservoirs of the Cantareira System, São Paulo, Brazil. (A) Porcentagens de larvas de Chironomidae com e sem alterações nas peças bucais. Os balóes indicam as proporções relativas por ponto amostral. (B) Regressão linear (intervalo de confiança a 95\%) entre as concentrações totais de cobre nos sedimentos $\left[\mathrm{C} u_{\text {sed }}\right]$ ( $\mathrm{mg} / \mathrm{Kg}$ ) e as proporções de alterações em peças bucais de larvas de Chironomidae (ALT) obtida a partir de dados provenientes de 207 larvas de Chironomidae distribuídas ao longo de seis pontos amostrais em três reservatórios do Sistema Cantareira, São Paulo, Brasil.

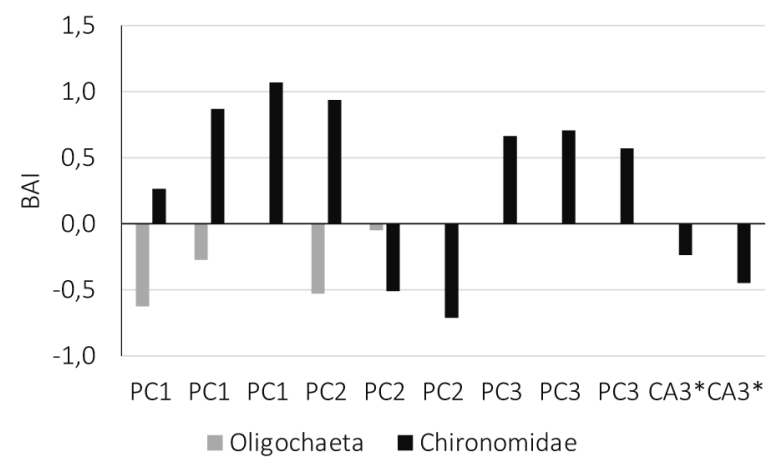

Figure 8. Bioaccumulation index (BAI) values calculated for Oligochaeta and Chironomidae from the Paiva Castro (PC, polluted area) and Cachoeira (CA3, non-polluted) reservoirs. *Other sampling points from Cachoeira were not analysed because of the low abundance of the organisms in CA1 and CA2. Índices de bioacumulação (BAI) calculados referentes a Oligochaeta e Chironomidae dos reservatórios Paiva Castro (PC, área poluída) e Cachoeira (CA, não-poluído). *Não foram analisados outros pontos do reservatório Cachoeira devido à baixa abundância de organismos em CA1 e CA2.

lished a provisional classification that considers values higher than 2 as indicating possible pollution.

Taking this into consideration, anthropic inputs of $\mathrm{Cu}$ were likely at PC1 and PC 3 but not at $\mathrm{PC} 2$ despite its higher concentration. Because PC2 was the only sampling point where $\mathrm{Cu}$ concentrations were higher than $25 \mathrm{mg} / \mathrm{L}$, and the BMI at PC2 presented morphological alterations and bioaccumulation, it is plausible that contamination by both $\mathrm{Cu}$ and $\mathrm{Al}$ occurred. This could have resulted from discharges of industrial sewage or the use of agricultural pesticides.

The correlation between $\mathrm{Cu}$ and $\mathrm{COM}$ could indicate some contribution from agricultural practices, considering that the use of $\mathrm{Cu}$-containing agrochemicals would lead to a situation where leaves carrying high amounts of $\mathrm{Cu}$ (Olu-Owolabi et al., 2013) would contribute to the metal entering into the aquatic system. In this case, it is plausible that a $\mathrm{Cu}-\mathrm{COM}$ correlation would be observed.

Nevertheless, the $\mathrm{Cu}-\mathrm{COM}$ relationship could simply be a consequence of water flow and the interaction between these two components. In the field at PC2, where a significantly high $\mathrm{Cu}$ concentration was noted, a reduced water flow was observed, along with the presence of macrophytes and proximity to trees in the margins. These conditions may favour COM and FS accumulation, and as consequence of the association of the metal with these particles (Wang \& $\mathrm{Li}, 2011), \mathrm{Cu}$ concentrations in PC2 would be noticeably high. More investigation is needed about this issue to clarify the possible anthropic sources of contamination. 
The correct evaluation of the biological component, especially of those organisms living in the sediments, may be the best option for monitoring and preventing environment damage by contaminated sediments (López-Doval et al., 2010; Picanço et al., 2014; Reis et al., 2014). Sediment quality guidelines have been developed using the relationships between sediment pollutant concentrations and biological responses with classifications, such as effects range low (ERL), effects range median (ERM), threshold effects level (TEL) and probable effects level (PEL), corresponding to the different probabilities of toxic effects (Long \& Morgan, 1991; Long \& MacDonald, 1992; MacDonald, 1994; Long et al., 1995). Comparison of the values obtained in our study with the TEL and PEL values showed that $\mathrm{PC} 1$ and $\mathrm{PC} 2$ exhibited $\mathrm{Cu}$ concentrations between these limits. The $\mathrm{Cu}$ concentration at PC3 was below the TEL (MacDonald, 1994).

The biological responses were in agreement with the predicted values (MacDonald, 1994). The proportion of mouthpart alterations in the chironomid larvae from PC2 was $37 \%$ (less than $50 \%$ ). At PC1, the proportion of alterations $(21 \%)$ could be expected at concentrations between the TEL and PEL or under the TEL limit, depending on the criteria adopted for estimating the TEL, which usually varies from 20-25\% (MacDonald, 1994; CCME, 1999). The PC3 value for ALT is comparable to that expected in environments with safe $\mathrm{Cu}$ levels (MacDonald, 1994).

The extrapolation from the linear model obtained in this study indicated that a $\mathrm{Cu}$ concentration of $58.60 \mathrm{mg} / \mathrm{Kg}$ was sufficient to cause mouth alterations in $50 \%$ of the chironomid larvae. This value is very different from the proposed PEL value of $108 \mathrm{mg} / \mathrm{Kg}$ (MacDonald, 1994). This could be explained by the fact that the present study was conducted in natural conditions at the community instead of at the population level. Many models adopted for use with experimental dose-response data are logistic but are based on single populations (Hochmuth et al., 2014; Zotti et al., 2013; Ritz, 2010). In addition, when a community with many different populations is considered, the tolerance varia- tions resulting from that diversity can linearize the model, as occurs in the dose-response curves obtained from many human cell populations instead of just one (White et al., 2009).

The bioaccumulation data clearly showed that $\mathrm{Cu}$ levels in the sediments from the Paiva Castro reservoir were sufficient to cause adverse effects in chironomids. Bioaccumulation was observed in 7 out of 15 samples. Differences in the intake and excretion of metals, as well as feeding habits, may help in understanding the bioaccumulation differences observed between the Oligochaeta and the Chironomidae (Wang \& Rainbow, 2008). The diversity of feeding habits among members of the family Chironomidae (Silva et al., 2009) and the positive relationship between $\mathrm{Cu}$ and COM should be considered to understand the observed differences at PC2. Considering the biological responses observed here, attention should be given to the risk of damage along the food chain affecting fishes (Kalantzi et al., 2014), as well as terrestrial ecosystems (from emergent aquatic insects) (Kraus et al., 2014).

We conclude that $\mathrm{Cu}$ levels higher than $13 \mathrm{mg} / \mathrm{Kg}$ were sufficient to cause observable morphological effects on chironomid larvae in the reservoirs studied. A linear model was able to represent the morphological response for the range of $\mathrm{Cu}$ concentrations considered here. Bioaccumulation was related to enrichment factors and differed according to the taxonomic group.

Our results permit us to recommend the use of morphological alterations in the mouthparts of chironomid larvae - considering, in principle, the entire taxonomic family in the aquatic environment - for biomonitoring. This approach has the advantage that environments with distinct taxonomic compositions may be monitored, which contrasts with the approach that considers just one species. The presence of bioaccumulation in invertebrates can be considered to be a warning about the risks for the ecosystem and for the people who ingest fishes from the Paiva Castro reservoir.

Future studies should include a risk-assessment approach that considers the distribution of copper along the food web and the possibilities 
of water contamination. Ecotoxicological assays may help to clarify how organisms respond to wider ranges of copper concentrations in situations where the other variables (biological and environmental) are standardized. Laboratory assays will also contribute to the understanding of how other environmental variables could change the biological responses.

\section{ACKNOWLEDGEMENTS}

The authors thank FAPESP (2013/03494-4; 2013/08272-0; 2012/11890-4) for financial support. We also thank Susana Trivinho Strixino, PhD, Humberto Fonseca Mendes, PhD, Julio López-Doval, PhD, Erik Sartori Jeunon Gontijo, MSc, Cláudia Hitomi Watanabe MSc. and Wálace Ânderson Almeida Soares, MSc for their valuable collaboration.

\section{REFERENCES}

AKCIL, A., C. ERUST, S. OZDEMIROGLU, V. FONTI \& F. BEOLCHINI. 2014. A Review of Approaches and Techniques Used in Aquatic Contaminated Sediments: Metal Removal and Stabilization by Chemical and Biotechnological Processes. Journal of Cleaner Production, 86: 24-36.

BEGHELLI, F. G. S., M. L. M. POMPÊO, C. H. WATANABE, A. H. ROSA \& MOSCHINICARLOS, V. 2014. Caracterização e análise de metais nos sedimentos da região litorânea de represas do Sistema Cantareira/SP. Proceedings of the 5 th Congresso Brasileiro de Gestão Ambiental. November, 24-27, 2014. Belo Horizonte, MG, Brazil.

BING, H., Y. WU, W. H. NAHM \& E. LIU. 2013. Accumulation of heavy metals in the lacustrine sediment of Longgan Lake, middle reaches of Yangtze River, China. Environmental Earth Sciences, 69: 2679-2689.

BIRD, G. A. 1994. Use of chironomid deformities to assess environmental degradation in the Yamaska River, Quebec. Environmental Monitoring and Assessment, 30: 163-175.

BLIJSWIJK, W. V., C. N. COIMBRA \& M. A. GRAÇA. 2004. The use of biological methods based on macroinvertebrates to an Iberian stream(Central Portugal) receiving a paper mill effluent. Limnetica, 23 (3-4): 307-314.

CARDOSO-SILVA, S. C. 2013. Metais-traço em sedimentos do reservatório Paiva Castro (MairiporãSão Paulo): histórico por meio da geocronologia do $210 \mathrm{~Pb}$, biodisponibilidade e uma proposta para a gestão dos recursos hídricos. Ph.D. Thesis, Universidade de São Paulo, São Paulo, Brazil.

CCME (Canadian Council of Ministers of the Environment). 1999. Protocol for the derivation of Canadian sediment quality guidelines for the protection for the aquatic life. Canada.

DI VEROLI, A., E. GORETTI, M. L. PAUMEN, M. H. S. KRAAK \& W. ADMIRAAL. 2012. Induction of mouthpart deformities in chironomid larvae exposed to contaminated sediments. Environmental Pollution, $166: 212-217$.

EL AZZI, D., J. VIERS, M. GUIRESSE, A. PROBST, D. AUBERT, J. CAPARROS, F. CHARLES, K. GUIZIEN \& J. L. PROBST. 2013. Origin and fate of copper in a small Mediterranean vineyard catchment: New insights from combined chemical extraction and $\delta 65 \mathrm{Cu}$ isotopic composition. Science of the Total Environment, 463-464: 91-101.

EPLER, J. H. 2001. Identification manual for the larval Chironomidae (Diptera) of North and South Carolina. North Carolina Department of Environment and Natural Resources. USA.

FONTANA, L., A. L. S. ALBUQUERQUE, M. BRENNER, D. M. BONOTTO, T. P. P SABARIS, M. A. F. PIRES, M. E. B. COTRIM \& D. C. BICUDO. 2014. The eutrophication history of a tropical water supply reservoir in Brazil. Journal of $\mathrm{Pa}$ leolimnology, 51: 29-43.

HOCHMUTH, J. D., J. ASSELMAN \& K. A. C. DE SCHAMPHELAERE. 2014. Are interactive effects of harmful algal blooms and copper pollution a concern for water quality management? Water Research, 60: 41-53.

HOGSDEN, K. L. \& J. S. HARDING. 2012. Anthropogenic and natural sources of acidity and metals and their influence on the structure of stream food webs. Environmental Pollution, 162: 466-474.

KALANTZI, I., N. PAPAGEORGIOU, K. SEVASTOU, K. D. BLACK, S. A. PERGANTIS \& I. KARAKASSIS. 2014. Metals in benthic macrofauna and biogeochemical factors affecting their trophic transfer to wild fish around fish farm cages. Science of the Total Environment, 470-471: 742753. 
KRAUS, J. M., T. S. SCHMIDT, D. M. WALTERS, R. B. WANTY, R. E. ZUELLIG \& R. E. WOLF. 2014. Cross-ecosystem impacts of stream pollution reduce resource and contaminant flux to riparian food webs. Ecological Applications, 24(2): 235-243.

LOGAN, M. 2010. Biostatystical design and analysis using R: A practical guide. Wiley Blackwell. West Sussex, UK.

LONG, E. R., \& D. D. MACDONALD. 1992. National status and trends program approach. In: Sediment classification methods compendium, EPA 82-3-R-92-006, B. Baker \& M. Kravitz, (ed): 14.1-14.18. United States Environmental Protection Agency, Office of Water (WH-56), Sediment Technical Oversight Committee, Washington, DC, United States of America.

LONG, E. R., D. D. MACDONALD, S. L. SMITH \& F. D. CALDER. 1995. Incidence of adverse biological effects within ranges of chemical concentrations in marine and estuarine sediments. Journal of Environmental Management, 19: 81-97.

LONG, E. R. \& M. G. MORGAN. 1991. The potential for biological effects of sediment-sorbed contaminants tested in the national status and trends program (Technical Memorandum). National Oceanic and Atmospheric Administration. Seattle, United States of America.

LÓPEZ-DOVAL, J. C., M. GROßSCHARTNER, S. HÖSS, C. ORENDT, W. TRAUNSPURGER, G. WOLFRAM, I. MUÑOZ. 2010. Invertebrate communities in soft sediments along a pollution gradient in a Mediterranean river (Llobregat, NE Spain), Limnetica, 29(2): 311-322.

MACDONALD, D. D. 1994. Approach to the assessment of sediment quality in Florida coastal waters. Vol. I.: MacDonald Environmental Sciences, Ltd., Ladysmith, Canadá.

MANDAVILLE, S. M. 2002. Benthic macroinvertebrates in freshwaters - taxa tolerance values, metrics and protocols. Soil and Water Conservation Society of Metro Halifax. Halifax, Canadá.

ODUME, O. N., W. J. MULLER, C. G. PALMER \& F. O. ARIMORO. 2012. Mentum deformities in Chironomidae communities as indicators of anthropogenic impacts in Swartkops River. Physics and Chemistry of the Earth, 50-52: 140-148.

OLU-OWOLABI, B. I., F. O. AGUNBIADE, B. O. FAGBAYIGBO \& K. O. ADEBOWALE. 2013. Monitoring Copper bioaccumulation in cocoa from Copper-based pesticide-treated cocoa farms using
Fuzzy similarity method. Bioremediation journal, 17(3): 131-147.

PICANÇO, T. C., C. M. R. ALMEIDA, C. ANTUNES \& P. A. REIS. 2014. Influence of the abiotic characteristics of sediments on the macrobenthic community structure of the Minho estuary saltmarsh (Portugal). Limnetica, 33(1): 73-87.

POMPÊO, M. L. M. 2012. Contaminação por metais pesados no sedimento de reservatórios do Sistema Cantareira (São Paulo): Perspectiva ou realidade? FAPESP-Auxílio Regular 2012 - Metais pesados nos sedimentos de represas. USP, São Paulo, SP, Brasil.

R CORE TEAM. 2013. R: A language and environment for statistical computing. R Foundation for Statistical Computing, Vienna, Austria.

REIS, P. A., L. GUILHERMINO, C. ANTUNES \& R. SOUSA. 2014. Assessment of the ecological quality of the Minho estuary (Northwest Iberian Peninsula) based on metal concentrations in sediments and in Corbicula fluminea. Limnetica, 33(1): 161173.

RITZ, C., 2010. Toward a unified approach to doseresponse modeling in ecotoxicology.. Environmental Toxicology and Chemistry, 29(1): 220-229.

RYU, J., J. S. KHIM, S-G. KANG, D. KANG, C. LEE \& C. KOH. 2011. The impact of heavy metal pollution gradients in sediments on benthic macrofauna at population and community levels. Environmental Pollution, 159: 2622-2629.

SANSEVERINO, A. M. \& J. L. NESSIMIAN. 2009. Fluctuating asymmetry in aquatic organisms and its application to evaluation of environmental impacts. Oecologia Australis, 12: 382-405.

SHAFIE, N. A., A. Z. ARIS, M. P. ZAKARIA, H. HARIS, W. Y. LIM, \& N. M. ISA. 2013. Application of geoaccumulation index and enrichment factors on the assessment of heavy metal pollution in the sediments. Journal of Environmental Science and Health Part A. 48: 182-190.

SILVA, F. L., G. M. PAULETO, J. L. B. TALAMONI, S. S. RUIZ. 2009. Categorização funcional trófica das comunidades de macroinvertebrados de dois reservatórios na região Centro-Oeste do Estado de São Paulo, Brasil. Acta Scientarium. Biological Sciences, 31(1): 73-78.

SOARES, W. A. A. 2012. Estudo da distribuição de metais em água, sedimentos e organismos aquáticos de rios e reservatórios pertencentes à Rede de Monitoramento da Qualidade dos Sedimentos do 
Estado de São Paulo, Brasil. Master's Thesis. Universidade de São Paulo, São Paulo, Brazil.

SUTHERLAND, R. A. 2000. Bed sediment-associated trace metals in an urban stream, Oahu, Hawaii. Environmental Geology, 39(6): 611-627.

TRIVINHO-STRIXINO, S. 2011. Larvas de Chironomidae: guia de identificação. gráfica da Universidade Federal de São Carlos, São Paulo, Brazil.

US-EPA(US Environmental Protection Agency). 1996. Method 3050B: Acid digestion of sediments, sludges, and soils. United States Environmental Protection Agency. Washington DC. USA.

VAROL, M. \& B. ŞEN. 2012. Assessment of nutrient and heavy metal contamination in surface water and sediments of the upper Tigris River, Turkey. Catena, 92: 1-10.

WALLS, L. D., L. Y. LI \& K. J. HALL. 2013. Trace Metal Contamination Due to Acid Rock Drainage and Its Impacts on the Fish-Bearing Pennask Creek Watershed, British Columbia. Water, Air and Soil Pollution, 224: 1675-1695.

WANG, W. X. \& P. S. RAINBOW. 2008. Comparative approaches to understand metal bioaccumulation in aquatic animals. Comparative Biochemistry and Physiology - Part C: Toxicology \& Pharmacology, 148: 315-323.

WANG, X. \& Y. LI. 2011. Measurement of $\mathrm{Cu}$ and $\mathrm{Zn}$ adsorption onto surficial sediment components: New evidence for less importance of clay minerals. Journal of hazardous materials, 189: 719-723.
WETZEL, R. G. \& G. E. LIKENS. 2000. Limnological analyses. Springer Science+Business Media, Inc. New York, United States of America.

WHATELY, M. \& P. CUNHA. 2007. Cantareira 2006: um olhar sobre o maior manancial de água da Região Metropolitana de São Paulo. Instituto Socioambiental. São Paulo, Brazil.

WHATELY, M. \& L. T. DINIZ. 2009. Água e esgoto na Grande São Paulo: Situação atual, nova lei de saneamento e programas governamentais propostos. Instituto Socioambiental. São Paulo, Brazil.

WHITE, R. H., I. COTE, L. ZEISE, M. FOX, F. DOMINICI, T. A. BURKE, P. D. WHITE, D. B. HATTIS \& J. M. SAMET. 2009. State-of-theScience Workshop Report: Issues and Approaches in Low-Dose-Response Extrapolation for Environmental Health Risk Assessment. Environmental Health Perspectives, 117(2): 283-287.

YI, Y., Z. YANG \& S. ZHANG. 2011. Ecological risk assessment of heavy metals in sediment and human health risk assessment of heavy metals in fishes in the middle and lower reaches of the Yangtze River basin. Environmental Pollution, 159, 2575-2585.

ZOTTI, M. J., A. D. GRUTZMACHER, I. H. LOPES $\&$ G. SMAGGHE. 2013. Comparative effects of insecticides with different mechanisms of action on Chrysoperla externa (Neuroptera: Chrysopidae): Lethal, sublethal and dose-response effects: Side-effect of insecticides on lacewing. Insect Science, 20: 743-752. 
